\title{
COST SAVINGS FROM PERFORMANCE-BASED MAINTENANCE CONTRACTING
}

\author{
Ad STRAUB \\ OTB Research Institute for Housing, Urban and Mobility Studies, \\ Delft University of Technology, PO Box 50302600 GA Delft, The Netherlands \\ E-mail: A.Straub@tudelft.nl
}

Received 23 February 2009; accepted 4 May 2009

\begin{abstract}
New procurement approaches combined with performance-based building approaches should reduce costs, but empirical qualitative and quantitative studies are lacking. Performance-based maintenance contracts give maintenance suppliers incentives to improve their way of working. Innovative, cost-effective solutions that meet the performance criteria can be achieved, especially if the principle of whole-life costing is being adopted. Indirect cost savings are expected as well. It enables maintenance contractors to assume responsibility for certain activities for which they are better equipped to perform than their clients. A calculation model was developed that calculates the net present value of the direct (product) and indirect (transaction) costs at project level for a competitive maintenance tendering approach and for performance-based maintenance contracts. The findings show that performance-based maintenance contracts reduce both direct and indirect costs compared to a competitive tendering approach. Essential preconditions are an early supplier involvement and longer term contracts, giving opportunities for maintenance product and maintenance process improvements.
\end{abstract}

KEYWORDS: Maintenance; Performance-based contracts; Transaction costs; Whole-life costing

\section{INTRODUCTION}

During the 1990s Dutch housing associations were transformed into so-called hybrid organisations, "combining task organization (implementing public tasks) and market organization (meeting market demands)" (Priemus, 2001: 247). Both their market and task operations forced housing associations to adopt a more structured approach to measuring and monitoring their performance. The drive towards more professional standards led to the adaptation of private sector approaches to public housing management (Nieboer and Gruis, 2004). The new market-based approach involved, among other things, the use of portfolio and asset management, outsourcing of non-core activities, the implementation of marketing techniques to attract potential tenants or buyers and a broadening in the supply of housing-related services.

The professionalism of Dutch housing associations has led to paying more attention to maintenance processes and partnerships in the supply chain of maintenance, leading to performance-based maintenance contracts too. The housing associations are permitted to use long term performance-based contracts, because European legislation for public tendering is not mandatory for them. 


\subsection{Maintenance tendering approaches}

Traditionally Dutch housing associations tender planned maintenance projects competitively and formulate technical specifications for the maintenance work. The client supervises the maintenance work on-site. This process is repeated every maintenance interval, defined as the period between major maintenance work to the same building component. This period coincides often the cycle of painting (six or seven years). In theory in a fixed-price competitive tendering approach the risk for the client is low and the risk for the contractor high. However, in practise the technical specifications are almost never completely finalised and in most cases this results in many change orders. Many Dutch housing associations hire consultants to assess conditions, to plan and to calculate maintenance, and to check on contractors.

The performance approach is, first and foremost, the practise of thinking and working in terms of ends rather than means. It is concerned with what a building is required to do, and not with prescribing how it is to be constructed (Meacham et al., 2005). In a performance-based maintenance relationship performance criteria are explicitly stated by the client (Straub, 2007). Performance-based contracting clearly alters the nature of the risk and its allocation, shifting increased risks on to the contractor and away from the client (Gruneberg et al., 2007).

In performance-based maintenance relationships, maintenance suppliers act as consultants, selected at an early stage, enabling them to contribute ideas about maintenance strategies, performance criteria, maintenance solutions and the financial aspects that apply to each building asset. In this approach a key issue is the re-design of the relevant building components by the contractor, to have a thorough command of the degradation process by taking the necessary initial maintenance activities. The re-design is an integral part of the specification phase. In the Dutch situation technical solutions are set down in maintenance scenarios and activity plans. A partnership agreement is concluded that covers a maintenance scenario consisting of several maintenance cycles that may last for the entire service life of the building (Straub, 2007). The client chooses a maintenance scenario based upon net present values of whole-life costs and related to the performances of the building components. The scenario and performance criteria are set down in a performance agreement. The contractors themselves monitor the degradation processes of building components by using performance measurements. The primary purpose of control and supervision by the client is to review the maintenance process, identify problems and then take the necessary action. They assess the completion of the work and the performance measurements done by the contractors. Contractors also monitor the entire maintenance process, especially customer satisfaction during maintenance interventions and thereafter.

There is a general belief that new procurement approaches combined with performancebased building approaches will improve performance and service and reduce costs (e.g. Bresnen and Marshall, 2000; Saad et al., 2002; Trimmer and Kidston, 2003). However, empirical qualitative and quantitative studies are scarce. Wood (2006) studied whether partnering is actually delivering win-win outcomes for both parties involved. He interviewed 10 major UK clients and 10 national contracting organizations. Lower costs for the client and guaranteed work for the contractor are the strongest and most consistent messages expressed by Wood's respondents. Black et al. (2000) surveyed by postal questionnaire clients, consultants and contractors involved in construction projects. Most benefits attributable to partnering expected from the parties are better relationships rather than project-based benefits (such as improved design, quality improve- 
ment, reduced cost etc.). "It can be inferred that because a better relationship between the parties produces the project-related benefits, the project-based benefits have not been rated highly by the respondents" (Black et al., 2000). Project-related benefits might become more obvious in performance-based maintenance relationships, especially if the whole service life of the building is involved and contractors keep responsibilities for a long period. Innovative, cost-effective solutions that meet performance criteria can be achieved, maintenance cycles can be extended, and change orders can be reduced. Moreover, efficient risk allocation will lead to cost savings.

\subsection{Research question}

The paper focuses on the cost savings of performance-based maintenance contracts compared to competitive maintenance tendering based upon technical specifications. The research question is: To what extent does performance-based maintenance contracts lead to project cost savings compared to the competitive way of tendering planned maintenance works? In the study the project costs have been calculated for two or more major maintenance cycles.

Next the research method is described, followed by the used calculation model, the researched projects, the findings of the study in the perspectives of whole-life costing and transaction costs, and the conclusions.

\section{RESEARCH METHOD}

In the research project a distinction has been made between direct project costs and indirect project costs. The direct project costs represent the product costs for maintenance work during a certain period. For the client actual payments to the contractor represent the product costs: the contract price. The indirect project costs are the transaction costs by the client and the contractor in connection with the procurement process. See Table 1. The overall project costs for the client include the contract price and his own transaction costs.

Non-project specific costs are relationshipspecific asset costs and overhead costs of contractors. Relationship-specific assets have little value outside a particular relationship of a client and a maintenance contractor. However, the costs of these assets are not-project specific but relationship-specific. In practise most contractors will be hired for several projects of a client. Examples of relationship-specific asset costs are a performance measurement method of the contractor adapted to the needs of the client and general agreements of clients and contractors. Relationship-specific asset costs and overhead costs were not implemented in the study.

Project-specific asset costs were implemented in the study. The tendering system influences directly the types and size of project asset specificity. Williamson (1996) distinguishes six types of asset specificity: (1) site specificity,

Table 1. Direct and indirect costs

\begin{tabular}{lll}
\hline & Direct costs & Indirect costs \\
\hline Project costs & $\begin{array}{l}\text { Product costs: } \\
\text { direct labour, materials, equipment, } \\
\text { transport }\end{array}$ & Transaction costs \\
Non-project specific costs & & $\begin{array}{l}\text { Relationship-specific asset costs } \\
\text { Overhead costs }\end{array}$ \\
\hline
\end{tabular}


(2) physical asset specificity, (3) human asset specificity, (4) dedicated assets, (5) brand name capital and (6) temporal specificity. For maintenance services human asset specificity that arises because individuals acquire specific skills by working for an organisation is the most obvious one (Lohtia et al., 1994). Van Mossel (2008) reflected on the types of asset specificity in maintenance: "Every maintenance solution is unique. A relatively complex building design is more likely to involve unique solutions, and therefore increases the challenges posed by asset specificity" (Van Mossel, 2008: 197). Van Mossel identifies the following types of (human) asset specificity in maintenance: (1) knowledge of the properties and maintenance solutions, (2) knowledge of the process, in particular at the operational level, (3) maintenance solutions, (4) offers by the maintenance firm and (5) built up experience and knowledge of the needs of end-customers. The product costs can be influenced if principles of life-cycle costing and whole-life costing are adopted. It is clear that the transaction costs can be influenced by the kind of relationship between the client and the contractor. The kind of specifications, either prescriptive or performance-based, may influence both.

\section{CALCULATION MODEL}

A calculation model was developed that calculates the net present value of the direct and indirect project costs at project level. The model used in an initial study was evaluated with employees of maintenance contractors and housing associations. The adapted model links the maintenance scenario and direct costs calculation directly to the indirect costs calculation and is more user-friendly. A manual was written for maintenance contractors and clients to fill in the model. This model includes project specific data, data about the maintenance scenarios (competitive and performance-based) and contract prices, and data about the indirect costs and the planning of future maintenance cycles. The initial process - the first maintenance cycle - and the subsequent processes consist of all activities conducted during a maintenance cycle. Following the initial maintenance process, one or more subsequent processes will take place. It is assumed that these subsequent processes will be equal in scope and transaction costs, although the actual maintenance activities and product cost undertaken in each can vary. The competitive maintenance scenario exists of equal recurring product costs every maintenance cycle. See Table 2.

Table 2. Calculation model for direct costs: product costs maintenance scenario

\begin{tabular}{|c|c|c|c|c|c|c|c|c|}
\hline & \multicolumn{4}{|c|}{ Competitive } & \multicolumn{4}{|c|}{ Performance-based } \\
\hline & Year & Activities & Costs & NPV & Year & Activities & Costs & $\mathrm{NPV}$ \\
\hline \multicolumn{9}{|l|}{0} \\
\hline \multicolumn{9}{|l|}{1} \\
\hline \multicolumn{9}{|l|}{2} \\
\hline \multicolumn{9}{|l|}{3} \\
\hline \multicolumn{9}{|c|}{$\cdots$} \\
\hline 30 & & & & & & & & \\
\hline
\end{tabular}

NPV $=$ Net Present Value 


\subsection{Tendering costs}

Waara and Bröchner (2006) argue that transactions costs for the contractor could easily be measured, being the bidding costs. Transaction costs for the client are less easily measured and arise through efforts to specify the project, to conduct the procurement process, to monitor the chosen contractor, and to resolve any conflicts related to the contract. Lingard et al. (1998) distinguish between ex-ante and ex-post transaction costs. Ex-ante costs include the costs of tendering, negotiating and writing the contract while ex-post costs may be incurred during the execution and policing of the contract or of resolving disputes arising from the contracted work. Hughes et al. (2006) explored the costs associated with different tendering approaches and contractual and non-contractual arrangements for collaboration. They relate the management costs to four stages in the commercial process: (1) Marketing (developing relationships and selling, including pre-qualification for preferred tender lists, forming alliances, establishing reputations), (2) Agreeing terms (pricing and scoping work, estimating, bidding and/or negotiating perhaps with some elements of design, and fixing a price), (3) Monitoring of work (managing the realization of the design, monitoring performance ensuring the carrying out of contractual obligations during the contract period) and (4) Resolving disputes (dispute resolution after the contract period).

The developed indirect cost model involves the transactions costs of the client and the contractor. We call the costs related to the first state of the commercial process 'marketing' relation-specific asset costs or overhead costs of the contractor. In long term performancebased maintenance relationships contractors' involvements enclose a part of the whole service life of a building. The indirect project costs depend on the process activities that must be conducted by the client and the contractor respectively throughout the maintenance period of the complex. The costs for providing advice about maintenance solutions and for conduct- ing performance measurement are being part of the bid price or priced separately.

The indirect cost model distinguishes 25 process activities based upon the competitive maintenance process and the performancebased maintenance process. The activities in the initial and subsequent processes are clustered into five phases: (1) specification, (2) selection, (3) contracting, (4) preparation, supervision and evaluation work and (5) after-care. The activities within the phase preparation, supervision and evaluation of the work, in the figures named work, do not involve the maintenance production itself. One can discuss if hours spend to e.g. site supervision are transaction costs or production costs. Anyhow various tendering approaches will lead to different time spending and costs. Table 3 shows a simplified example of a time sheet of the indirect cost model. In each column the client and the contractor has to fill in the hours spend on the activity. Labour costs are calculated depending on the wage scale. The costs are based on a differentiation in hourly charges per activity, with the level of charges depending on the various wage scale groups applied by both the client and the contractor. The model assumes that each party will have three such groups. Third parties, such as consultants or inspection agencies, may perform some activities; the costs involved being charged to the client and/or contractor.

\section{PROJECTS}

An initial study included ten projects. In order to make a thorough comparison, 12 more projects were selected. Each project involves exterior maintenance of housing estates owned and managed by a housing association. The projects are owned and managed by 13 different housing associations and maintained by 9 different maintenance contractors. The number of projects of one housing association is between 1 and 4 ; the number of projects of one contractor is between 1 and 6 . The cost comparison assumed a performance-based approach, with the applicable basic premises 
Table 3. Calculation model for indirect costs: time sheet for project hours of the initial maintenance process

\begin{tabular}{|c|c|c|c|c|}
\hline & \multicolumn{2}{|c|}{ Competitive } & \multicolumn{2}{|c|}{ Performance-based } \\
\hline & Client & Contractor & Client & Contractor \\
\hline \multicolumn{5}{|l|}{ Specification } \\
\hline 1. Inspection & & N/A & N/A & N/A \\
\hline 2. Formulating technical specifications & & N/A & N/A & N/A \\
\hline 3. Formulating functional and performance criteria & N/A & N/A & & N/A \\
\hline \multicolumn{5}{|l|}{ Selection } \\
\hline 4. Selection of contractors & & N/A & & N/A \\
\hline \multicolumn{5}{|l|}{ Contracting } \\
\hline $\begin{array}{l}\text { 6. Consultation about functional specifications } \\
\text { and performance criteria }\end{array}$ & N/A & N/A & & \\
\hline \multicolumn{5}{|l|}{ 7. Inventory } \\
\hline \multicolumn{5}{|l|}{ 8. Condition assessment } \\
\hline \multicolumn{5}{|l|}{ 9. Collecting external advice } \\
\hline 10. Inviting tenders and assessment subcontractors & N/A & & N/A & \\
\hline 11. Designing or adjusting maintenance scenario's & N/A & N/A & N/A & \\
\hline \multicolumn{5}{|l|}{ 12. Formulating or adjusting offer } \\
\hline 13. Assessment offers & & N/A & & N/A \\
\hline \multicolumn{5}{|l|}{ 14. Consultation about offers } \\
\hline \multicolumn{5}{|l|}{ 15. Working out and consultation about activity plans } \\
\hline \multicolumn{5}{|l|}{ 16. Commissioning and confirmation work } \\
\hline \multicolumn{5}{|l|}{ Preparation, supervision and evaluation work } \\
\hline \multicolumn{5}{|l|}{ 17. Preparation project } \\
\hline \multicolumn{5}{|l|}{ 18. On-site supervision } \\
\hline \multicolumn{5}{|l|}{ 19. Supervision project } \\
\hline \multicolumn{5}{|l|}{ 20. Project delivery and Final acceptation inspection } \\
\hline \multicolumn{5}{|l|}{ 21. Project process evaluation } \\
\hline \multicolumn{5}{|l|}{ 22. Customer satisfaction evaluation } \\
\hline \multicolumn{5}{|l|}{ After-care } \\
\hline \multicolumn{5}{|l|}{ 23. Performance measurements } \\
\hline \multicolumn{5}{|l|}{ 24. Consultation performance measurements } \\
\hline 25. Settle performance guarantees & & & & \\
\hline
\end{tabular}

N/A = not applicable

in terms of performance level and maintenance period. The contractors had produced a maintenance scenario, including a price, for this period. The maintenance scenario influences both the direct and the indirect costs. For this research project another maintenance scenario was designed by the client and contractor representing the competitive tendering approach. The notional direct and indirect costs of this scenario were estimated, based on the performance level and maintenance period of the performance-based scenario. The maintenance history of the building played a significant part here. It was assumed that the direct costs of painting - including preventative maintenance work - are cyclically recurrent.

Presumably the size and scope of the project will influence the proportion between direct 
and indirect project costs per procurement approach. Here a distinction has been made between 'simple' projects, 'complex' projects and 'total maintenance projects', depending on the scope and type of maintenance work involved, and the lead-time of the (initial) maintenance process. Ten projects could be classified as 'simple', 7 projects as 'complex' and 5 projects as 'total maintenance'.

The projects studied vary in terms of the characteristics of each housing estate, their size, maintenance history and original quality, and working methods. Accordingly, they are not directly comparable one against the other. However, each project enables a comparison to be made between performance-based maintenance contracting and competitive maintenance tendering in terms of direct and indirect project costs. Table 4 gives the project characteristics. The distribution of size and construction years of the projects is large. The number of dwellings is between 27 and 360 .

Table 4. Project characteristics

\begin{tabular}{|c|c|c|c|c|c|c|}
\hline \multirow[t]{2}{*}{ Housing estate } & \multirow[t]{2}{*}{ Dwellings } & \multirow{2}{*}{$\begin{array}{l}\text { Construction } \\
\text { year }\end{array}$} & \multirow{2}{*}{$\begin{array}{l}\text { Dwelling } \\
\text { type }\end{array}$} & \multirow{2}{*}{$\begin{array}{l}\text { Performance- } \\
\text { based } \\
\text { contract } \\
\text { period * }\end{array}$} & \multicolumn{2}{|l|}{ Direct costs } \\
\hline & & & & & $\begin{array}{l}\text { Calculated } \\
\text { price } \\
\text { competitive } \\
\text { per dwelling }\end{array}$ & $\begin{array}{l}\text { Contract price } \\
\text { performance- } \\
\text { based per } \\
\text { dwelling }\end{array}$ \\
\hline \multicolumn{7}{|l|}{ Simple projects } \\
\hline Guldenslag & 111 & $1989 / 1990$ & $\begin{array}{l}\text { Single- and } \\
\text { multi-family }\end{array}$ & 12 & 2,916 & 2,788 \\
\hline Menkamaborgstraat & 47 & 1988 & Single-family & 6 & 1,713 & 1,627 \\
\hline Laan v.d. Bork & 88 & 1971 & Single-family & 28 & 14,814 & 11,465 \\
\hline Dopperlaan & 32 & 1967 & Single-family & 28 & 10,680 & 7,739 \\
\hline Emmalaan, Meerveld & 94 & 1976 & Single-family & 28 & 5,551 & 4,452 \\
\hline Koekoekstraat & 28 & 1997 & Multi-family & 30 & 3,229 & 2,478 \\
\hline Vrijmoedhof & 92 & 1971 & Multi-family & 30 & 2,687 & 2,687 \\
\hline Platte Daken & 178 & 1967 & Single-family & 24 & 3,928 & 3,928 \\
\hline Geroflat & 360 & 1968 & Multi-family & 22 & 2,324 & 1,894 \\
\hline Lelie & 68 & 1990 & Multi-family & 28 & 2,929 & 2,540 \\
\hline \multicolumn{7}{|l|}{ Complex projects } \\
\hline Spaarnestraat & 52 & 1933 & Single-family & 30 & 20,507 & 20,507 \\
\hline Van Tuylkade & 204 & 1950 & Multi-family & 23 & 10,284 & 9,172 \\
\hline Eikenlaan e.o. & 102 & 1949 & Single-family & 18 & 6,192 & 4,169 \\
\hline Akkers 6 & 179 & 1980 & $\begin{array}{l}\text { Single- and } \\
\text { multi-family }\end{array}$ & 14 & 5,000 & 4,303 \\
\hline Eksterstraat & 103 & 1967 & Single-family & 28 & 10,329 & 9,379 \\
\hline Celebesstraat & 28 & 1970 & Single-family & 29 & 13,763 & 13,023 \\
\hline Complex 206 & 27 & 1987 & Single-family & 15 & 9,691 & 8,926 \\
\hline \multicolumn{7}{|c|}{ Total maintenance projects } \\
\hline Turpijnplaats & 198 & 1972 & Multi-family & 30 & 32,904 & 21,802 \\
\hline Palazzo & 60 & 1995 & Multi-family & 30 & 34,237 & 27,782 \\
\hline $\begin{array}{l}\text { ML Kingstraat/ } \\
\text { Mandela }\end{array}$ & 69 & 1995 & Single-family & 30 & 23,993 & 22,496 \\
\hline Gandhihof & 52 & 1995 & Single-family & 30 & 17,680 & 16,615 \\
\hline Eekhoornweide & 45 & 1978 & Single-family & 28 & 16,008 & 14,456 \\
\hline
\end{tabular}

*excluding the performance guarantee period after the final maintenance interval 
One housing estate was built before the Second World War. The housing estates involve single- en multi-family dwellings.

Generally, the competitive tendering approach as well as the performance-based approach of both the clients and contractors shows a great variety. There are differences in process steering by the housing association closely connected with the given freedom in maintenance solutions by contractors and the monitoring of performance by contractors and/or third parties commissioned by the client. Experience may affect the product costs as well as the transaction costs. Two of the 13 involved housing associations were not experienced in performance-based maintenance contracts. That means that the projects in this research were pilot projects for performancebased contracting. The number of performancebased maintenance contracts of experienced housing associations differs strongly. Just a few clients see performance-based contracting as the only procurement method and apply this approach for all their housing estates.

\section{FINDINGS}

From the results the overall project costs appear to be lower for performance-based partnering than for competitive maintenance tendering. This concerns all kind of projects. The

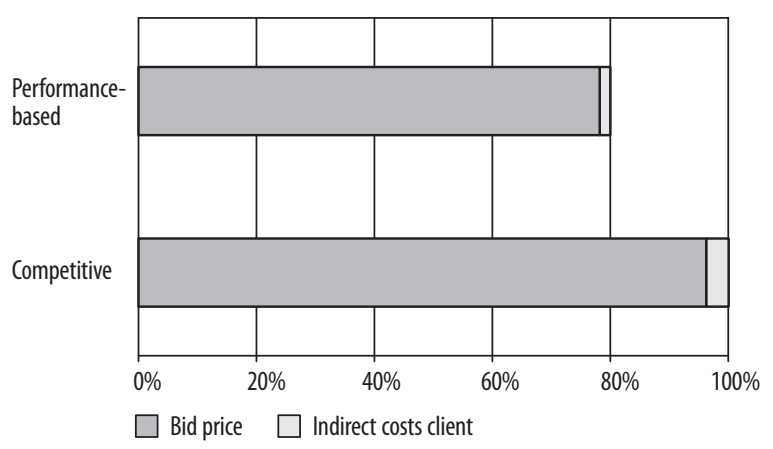

Figure 1. Average overall costs client, initial process and subsequent processes average overall project costs difference is $20 \%$. In all projects the direct costs (contract price minus the indirect costs of the contractor) of performance-based contracting are lower, or at worst the same, as for competitive maintenance tendering. The share of the indirect costs of the client in the overall project costs is for both tendering approaches small (2-5\%). The cost savings on contract prices by performance-based contracting are the biggest for 'total maintenance projects', followed by 'simple projects'. See Figure 1. In the figures the competitive maintenance tendering approach is the index of $100 \%$.

The indirect costs of the client are lower in case of performance-based contracting in the initial process as well as in subsequent processes. On average for all projects the indirect costs of the client are $51 \%$ lower in case of performance-based contracting. See Figure 2.

In all phases with the exception of 'aftercare', the costs of performance-based contracting are lower. Cost savings are relatively the biggest for the phases of 'specification' and 'selection'. Because of the fact that the client will continue the relationship with the contractor after the initial process, time and cost being spent for selection are in subsequent processes very low. See Figure 3. Cost savings in contracting and in work and supervision are very clear in the subsequent processes. Not surprisingly is that the client spends more time and

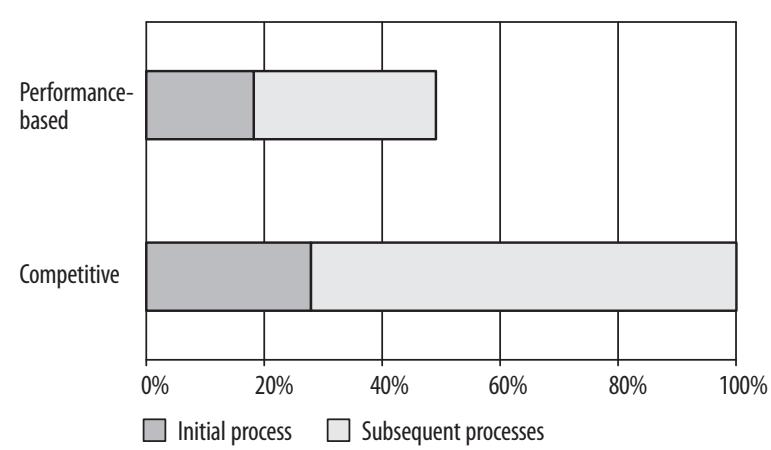

Figure 2. Average indirect costs client, initial process and subsequent processes 


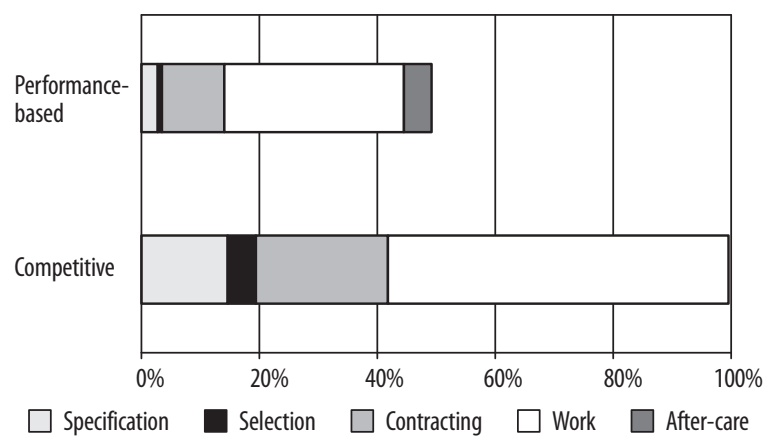

Figure 3. Average indirect costs client, initial process and subsequent processes per phase

money for after-care if applying a performancebased relationship.

The indirect costs of the contractors are part of the contract price. This research project made these costs transparent. Contractors are not involved in the phases of 'specification' and 'selection'. On average the indirect costs of the contractors are $21 \%$ lower in the case of performance-based contracting. See Figure 4. During the initial process contractors spend on average more hours. The expectation was that 'simple projects' are an exception, but this is not true. Contractors spend also more hours in most of the simple projects during the initial process if working performancebased compared to competitive maintenance tendering. Clients give contractors free reins. Traditionally in a competitive market there is inadequate time to prepare a tender. Contractors spend relatively much time in the phase of 'after-care' if working performance-based. Those 'extra' hours are amply compensated by saving hours in the process phases contracting and work and supervision, especially during subsequent maintenance processes.

\subsection{Product costs and whole-life costing}

If principles of whole-life costing are adopted in the maintenance re-design and maintenance scenario, reducing of the product costs could be realized by:

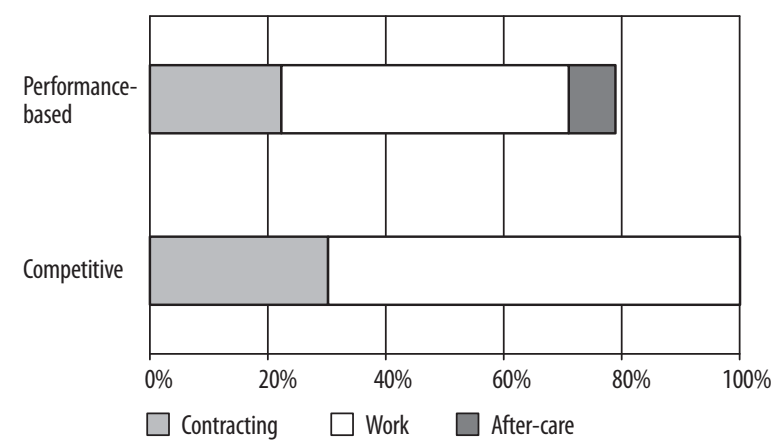

Figure 4. Average indirect costs contractor, initial process and subsequent processes per phase

- planning the maintenance activities according to the existing level of quality, the desired quality and the desired service life of a building;

- ensuring better coordination between work to substrates and to the finishing (paintwork);

- conducting maintenance activities 'justin-time' based upon performance measurements.

The performance-based relationship offers the contractor greater opportunities to plan the maintenance activities to the requirements of the client during the duration of the maintenance period, and to coordinate maintenance activities with each other. This is the result of the contractor's long term involvement in, and responsibility - including financial responsibility - for the maintenance project under the performance-based contract. The fact that the same contractor takes responsibilities for both the paintwork and maintenance work to the substrates is also important. In the initial process, a thorough analysis of the causes of defects will be conducted. The contractor will select the solution offering the lowest costs over the entire service life. Performance-based contracting offers a better guarantee of actually achieving the advantages of condition-based maintenance than the competitive approach, since it is the contractor who conducts the per- 
formance measurements and who also bears the risks relating to the timely performance of maintenance activities. The deterioration can be predicted more accurately and maintenance cycles may be extended, for example the cycle of paintwork from six to seven years. Accordingly, in a maintenance scenario of thirty years, there would be only four maintenance cycles in stead of five.

The findings show that long term performance-based contracts have potential for production cost improvements, but there are some practical barriers to implement the principles of whole-life costing by contractors. Pasquire and Swaffield (2002) list barriers to successful implementation of life-cycle costing and wholelife costing techniques: availability of suitable data, project finances, short term interest of clients, professional fees and taxation issues. Housing associations have a long term interest in their properties, but long term maintenance contracts may involve performance improvements. Those improvements are financed through housings associations' capital budgets. Maintenance budgets are usually under the control of a separate department. If housing estates are being refurbished main emphasis is placed on minimising the initial capital costs with little regard for the maintenance costs. Another barrier is the desired flexibility in maintenance policy-making by Dutch housing associations. The contractor designs a maintenance scenario for a longer period. However, the legal contract period should just expand just one or two maintenance cycles to give owners their desired flexibility.

\subsection{Transaction costs}

Client and contractor both make transaction costs. In theory, ex ante and ex post transaction costs are interdependent. Reducing of the transaction costs can be realized by performing process activities by the client or contractor that is best equipped to perform the acti- vity and by a better management of the entire maintenance process.

Lai et al. (2006) argue that a lesser input of ex ante resources would result in a less proper contract that requires more ex post management efforts. The relationship between contract monitoring cost, which may vary with the propriety of contract, complexity of work, contractual relationship, capability and quality of contractor and management teams and the monitoring effort is unknown (Lai and Yik, 2007). We expect that in a performance-based maintenance approach the contract monitoring cost will be high at the start of the partnership and become less during the contact period. The used calculation model was not appropriate to underpin this expectation.

Hughes et al. (2006) expect that collaboration or other means of re-organising the construction process will transfer the tendering costs to more productive activities. Our findings support this expectation for maintenance projects. In the competitive maintenance tendering approach, specification of the work by the client is time consuming, especially for more complex projects. Often information of executed projects is lost following the once-only tendering process. Besides many activities of the specification and contracting phase are duplicated, i.e. conducted by both client and contractor, e.g. inventory, condition assessment and supervision. In the performancebased approach, clear agreements are made with regard to which party is responsible for which activity during the contract period. Theoretically on-site supervision by the client is not needed if performances are specified. Indirect cost reductions are become particularly apparent after the initial process. The costs of collecting project information, consultation, condition assessments and the design of alternative maintenance scenarios will decrease dramatically due to the continuity of the performance-based contract. 


\section{CONCLUSIONS}

Long term, performance-based contracting offers many advantages compared to the competitive tendering approach. One of the main benefits is that long term performance-based contracting reduces both direct and indirect costs. The essential preconditions are long term involvement and freedom in the maintenance design and process for the contractor, giving opportunities for product and maintenance process improvements. The findings show that average overall project costs are $20 \%$ lower. The process phases 'specification', 'selection', 'contracting' and 'work and supervision' become markedly less expensive in case of performance-based contracting. The 'after-care' phase is markedly more expensive in every project when the performance-based approach is adopted, because of conducting periodic performance measurements. For the contractor the initial process is more expensive within the performance-based approach. That this method is nevertheless less expensive overall for the contractor is due to the cost reductions in the subsequent processes. Indirect cost reductions become particularly apparent following the initial process, once both parties have gained experience with the project. The direct costs can be reduced not only in terms of savings on manpower and materials, but also - and especially - in terms of incidental costs such as the hire of scaffolding and site costs. Scaffolding hire represents a growing proportion of the total direct project costs. Longer maintenance cycles enable this type of expenditure to be reduced significantly.

Quantifying the costs of tendering is not easy. Hughes et al. (2006) found that one of the most significant findings from the attempts at quantifying the costs of tendering is that the number of variables is huge, and it is impossible to isolate factors that influence costs directly. The scope of this study is much broader than tendering costs. The study encompasses the transactions costs of the contractor and the client and the product costs of different procurement approaches. This means that the outcomes of the study should be interpreted by some limitations. The most important one is that the cost comparison assumed a performance-based approach and that the time sheets had to be filled in for spended hours and for expected hours to be spend at process activities. Contractors spend more hours during the initial process of working performance-based compared to competitive tendering, because of the (intention to) long term involvement. This means that a better estimation can be given in the performance-based maintenance scenario.

The client's initial selection of contractors is likely to cost more time in the performance-based approach than in a competitive tendering approach with technical specifications. The selection will not be made for each individual project, but the client will divide all his projects among a number of pre-selected contractors. Prior to the initial phase of the first project (or projects) the client and contractors will be required to devote considerable time to seeking out the most appropriate partnership form(s), agreeing unit prices and decisive performance indicators, and drawing up the relevant framework contracts. However, these activities are also part of the traditional process, albeit under different names. Like selection, the evaluation of contractors and the assessment of customer satisfaction will also take place outside the confines of individual projects, although project-related aspects will also be taken into account in the evaluation.

In performance-based contracts maintenance activities are assigned to the contractor for a long period, covering a number of subsequent processes and maintenance cycles. This means that it is no longer necessary to re-bid for each period. This continuity will result in lower indirect project costs throughout the subsequent processes for the contractor. The findings show that on average the indirect costs of 
the contractor are $21 \%$ lower in the case of performance-based contracting. This means that new activities by contractors, especially advice about maintenance solutions and performance measurement, do not raise contractors' transaction costs, at least on the project level. The execution of these activities demands additional capabilities from the contractor (Straub and Van Mossel, 2007); relationship- specific asset costs and overhead costs may increase. Moreover maintenance contractors must be able to achieve a sufficient level of turnover for performance-based contracts in order to be able to perform these 'advisory tasks' in a satisfactory manner. Due to the continuity of the performance-based contracts maintenance contractors can improve their internal business processes, with more efficient logistical deployment of manpower and equipment, and more efficient purchasing of materials. This will reduce the overhead costs.

In a traditional multiple, competitive tendering process a lower contract price may be the outcome compared to the price of a performance-based contract. This is especially the case in very competitive markets, like the Dutch maintenance market at present. However, on the long term and under changing market circumstances, clients and contractors believe that this will have no effect.

\section{REFERENCES}

Black, C., Akintoye, A. and Fitzgerald, E. (2000) An analysis of success factors and benefits of partnering in construction, International Journal of Project Management, 18(6), pp. 423-434.

Bresnen, M. and Marshall, N. (2000) Partnering in construction: a critical review of issues, problems and dilemmas, Construction Management and Economics, 18(2), pp. 229-237.

Gruneberg, S., Hughes, W. and Ancell, D. (2007) Risk under performance-based contracting in the UK construction sector, Construction Management and Economics, 25(7), pp. 691-699.

Hughes, W., Hillebrandt, P.M., Greenwood, D. and Kwawu, W. (2006) Procurement in the con- struction industry: the impact and cost of alternative market and supply processes, Taylor \& Francis, London.

Lai, J.H.K., Yik, F.W.H. and Jones, P. (2006) Critical contractual issues of outsourced operation and maintenance service for commercial buildings, International Journal of Service Industry Management, 17(4), pp. 320-343.

Lai, J.H.K. and Yik, F.W.H. (2007) Monitoring building operation and maintenance contracts, Facilities, 25(5/6), pp. 238-251.

Lingard, H., Hughes, W.P. and Chinyio, E.A. (1998) The impact of the contractor selection method on transaction costs: a review, Journal of Construction Procurement, 4(2), pp. 89-102.

Lohtia, R., Brooks, C.M. and Krapfel, R.E. (1994) What constitutes a transaction-specific asset? An examination of the dimensions and types, Journal of Business Research, 30(3), pp. 261270.

Meacham, B., Bowen, R., Traw, J. and Moore, A. (2005) Performance-based building regulation: current situation and future needs, Building Research \& Information, 33(2), pp. 91-106.

Nieboer, N. and Gruis, V. (2004) The Netherlands. In: Gruis, V. and Nieboer, N. (eds.) Asset Management in the Social Rented Sector: Policy and Practice in Europe and Australia, Springer/ Kluwer Academic Publishers, Dordrecht.

Pasquire, C. and Swaffield, L. (2002) Life-cycle/ Whole-life costing. In: Kelly, J., Morledge, R. and Wilkinson, S. (eds.) Best value in construction, Blackwell Sciences, Oxford.

Priemus, H. (2001) Social housing as a transitional tenure: reflection on the Netherlands social housing memorandum 2000-2010, Housing Studies, 16(2), pp. 243-256.

Saad, M., Jones, M. and James, P. (2002) A review of the process towards the adoption of supply chain management (SCM) relationships in construction, European Journal of Purchasing \& Supply Management, 8(3), pp. 173-183.

Straub, A. (2007) Performance-based maintenance partnering: a promising concept, Journal of $\mathrm{Fa}$ cilities Management, 5(2), pp. 129-142.

Straub, A. and Van Mossel, J.H. (2007) Contractor selection for performance-based maintenance partnerships, International Journal of Strategic Property Management, 11(2), pp. 65-76.

Trimmer, G. and Kidston, N. (2003) Assessing procurement, Trimmer CS and The Housing Corporation, London. 
Van Mossel, J.H. (2008) The purchasing of maintenance service delivery in the Dutch social housing sector. Optimising commodity strategies for delivering maintenance services to tenants, IOS Press, Amsterdam.

Waara, F. and Bröchner, J. (2006) Price and nonprice criteria for contractor selection, Journal of Construction Engineering and ManagementASCE, 123(8), pp. 797-804.
Williamson, O.E. (1996) The mechanisms of governance, Oxford University Press, New York.

Wood, G. (2006) Addressing the economic realities of partnering arrangements within the UK construction industry. In: Mc Dermott, P. and Khalfan, M.M.A. (eds.) Proceedings of the Symposium on Sustainability and Value through Construction Procurement 2006, University of Salford, Salford, pp. 614-625.

\section{SANTRAUKA}

\section{TAUPYMAS NAUDOJANT VEIKLOS REZULTATAIS PAGRISTAS PRIEŽIŪROS SUTARTIS}

\section{Ad STRAUB}

Nauji pirkimo būdai, derinami su subalansuotos statybos būdais, turètų mažinti išlaidas, tačiau trūksta empirinių kokybinių ir kiekybiniu tyrimų. Veiklos rezultatais pagrịstos priežiūros sutartys skatina priežiūros paslaugas siūlančias bendroves tobulinti savo darbo būdus. Galimi novatoriški, taupūs sprendimai, tenkinantys rezultatyvios veiklos kriterijus, ypač taikant viso naudojimo laiko išlaidu (angl. whole-life costing) principa. Tikimasi sumažinti ir netiesiogines išlaidas. Priežiūra atliekantiems rangovams tai leidžia prisiimti atsakomybę už tam tikra veikla, kuriai vykdyti jie turi daugiau priemonių nei jų klientai. Sukurtas skaičiavimo modelis, kurị taikant apskaičiuojama viso projekto tiesioginių (produktas) ir netiesioginiu (sandoris) sąnaudų dabartinè grynoji vertè (NPV), kai vykdomas priežiūros darbų pirkimo konkursas ir kai sudaromos veiklos rezultatais pagrisstos priežiūros sutartys. Rezultatai rodo, kad, lyginant su pirkimo konkursais, veiklos rezultatais pagrǐstos priežiūros sutartys mažina ir tiesiogines, ir netiesiogines išlaidas. Būtinos salygos - įtraukti i̇ priežiūros vykdymą tiekèja ankstyvuosiuose etapuose ir sutartis sudaryti ilgesniam terminui, suteikiant galimybių tobulinti produktą ir priežiūros procesa. 